MATEC Web of Conferences 47, 04013 (2016)

DOI: $10.1051 /$ matecconf/20164704013

(C) Owned by the authors, published by EDP Sciences, 2016

\title{
The Insight of Industrialised Building System (IBS) By Bumiputera Construction Players
}

\author{
W. M. N. W. Muhammad ${ }^{1, a}$, M. A. Azman ${ }^{1}$, M. K. F. Othman ${ }^{1}$, N. A. Hadi ${ }^{1}$, S. N. S. Sahimi ${ }^{1}$ and M. F. \\ Mohammad $^{2}$ \\ ${ }^{1}$ Faculty of Architecture, Planning and Surveying, Universiti Teknologi Mara, 94300 Kota Samarahan, Sarawak, \\ Malaysia \\ ${ }^{2}$ Faculty of Architecture, Planning and Surveying, Universiti Teknologi Mara, 40450 Shah Alam, Selangor, Malaysia
}

\begin{abstract}
The term Industrialised Building System (IBS) is widely recognised by construction players in Malaysia since its first implementation since 1960s for IBS pilot projects of Pekeliling Flats and Rifle Range Flats. The aim for the implementation is to promote better system in delivering construction end-products which offers efficiency and effectiveness. At the same time, Bumiputera construction players are the majority of parties in construction industry especially in Small and Medium Enterprises (SMEs). Therefore, the purpose of this paper is to identify the perception and awareness of IBS implementation among Bumiputera players. It is found that, Bumiputera construction players have sound knowledge on the IBS and optimistic towards further implementation for future projects. Nonetheless, issues on payment methods and coordination of IBS project delivery are found to be the negative perceptions which are considered as hindrance for Bumiputera construction players' involvement in IBS project.
\end{abstract}

\section{Introduction}

The Malaysian Construction Industry has recently been geared by the government with the term of Industrialised Building System (IBS) to represent the adoption of the construction industrialised and the use of prefabrication of components in building construction. To make the interpretation clearer, IBS is defined as a construction technique in which components are manufactured in a controlled environment (on or off site), transported, positioned and assembled into a structure with minimal additional site work [1, 2, 3]. To support this definition, an Industrialised Building System may be defined in which all building components such as wall, floor slab, beam, column and staircase are mass produced either in factory or at site under strict quality control and minimal on site activities [4]. This profitable system can produce high quality product in future, minimise the resource wastage and enhance the value of end products. This is further supported with the argument that an industrialisation process is an investment in equipment, facilities, and technology with the objective of maximising production output, minimising labour resource, and improving quality [4]. Construction Industry Development Board (CIDB) has classified the system into 6 categories which are precast concrete framed system, formwork system, steel framing system, prefabricated timber framing

\footnotetext{
${ }^{a}$ Corresponding author : neodanish@gmail.com
} 
system, block work system and innovative system [5]. The classification is being classified according to the structural aspects for each component.

IBS has been successfully implemented in Japan, United Kingdom, Sweden and also Netherlands [5]. Apart from that, this IBS system has also being applied in Hong Kong and Singapore [6]. It has been well establish in many part of the world. The implementation of IBS in Malaysia is not at infancy stage. IBS has been already being introduced in early 1960s. This was when Public Work Department (PWD) and Ministry of Housing and Local Government (MHLG) of Malaysia visited several European countries and evaluate their housing development program. IBS in Malaysia was first initiated in two pilot projects in Jalan Pekeliling, Kuala Lumpur and Rifle Range, Penang with a series of 17 and 18-storey flats. Throughout the period, IBS was anticipated to change and to be used in a broader scale [6].

Key players who are directly connected to IBS construction are client, designer, contractor and specialist manufacturer [6]. Bumiputera contracting firms only started to get in the industry after the application of the New Economic Policy (NEP) in 1970 [7]. The government has implemented the NEP with the purpose to attract more Bumiputera businesses to get involved in economic activities. Construction industry was one of the main sectors that recorded high involvement of Bumiputera entrepreneurs [7]. To improve this, the government plays an important role in promoting the Malay or Bumiputera entrepreneur's development in the industry. In order to operate any construction, contracting firms need to get registered with two government agencies which are Pusat Khidmat Kontraktor (PKK) and also Construction Industrial Development Board (CIDB). PKK has been establishing in year of 1981 where their responsibilities are to register, lead and train especially the Bumiputera entrepreneurs that involves in the industry. Meanwhile, CIDB was only established 13 years after that which is in 1994. The objectives of the establishment are to control all activities in the industry especially on the contractor's registration, worker training, site safety, material controlling and also on the foreign workers. With the significant involvement of Bumiputera in Malaysia construction industry, it is important to gain the Bumiputera construction players' insight towards the adaptation and implementation of IBS among them. This is indispensable in order to sustain the involvement of Bumiputera in construction industry as well as to keep abreast with the current needs of IBS application by construction players. Several initiatives are already being conducted by Government and CIDB in order to promote IBS among Bumiputera construction players such as tax reduction incentives for Bumiputera components manufactures since 2005 and offer training scheme and financial loans for Bumiputera manufacturer and installer since 2004 [8]. However, the participation from Bumiputera being part of the construction players as to be a contractor neither to be a manufacturer was insufficient in IBS practice. This is highlighted by the failure in achieving Key Performance Index (KPI) for the Bumiputera Development category in IBS Roadmap 2003-2010 [9]. Hence, it is important to focus on the participation by Bumiputera since previous literature has shown that one of the barriers of the implementation of IBS is due to lack of involvement by Bumiputera as the contractors, erectors and manufacturers [3].

\section{Methodology and Findings}

The focus of this study is on getting the insight of the Bumiputera construction players towards IBS implementation in Malaysia. The quantitative research has been carried out with the respondents for this study comprise of Bumiputera constructors as the party that directly involved in the utilisation of IBS in construction and Bumiputera client as the owner as well as the end user of the building. The total of 250 questionnaires were prepared and distributed to both parties in gaining the respondent's feedback and 29.2\% (73) of questionnaires distributed were returned. The returned questionnaire were being analyse using Statistical Package for Social Science (SPSS) version 16.0. The number of questionnaires received is considered acceptable enough by considering the population studied. The non-parametric statistical methods such as Mann-Whitney $U$ was selected due to the nature of the instrument designed through the use of questionnaire which was assumed to be skewed. The results have been tabulated in sections. Section 1 presents respondents' background such as designation, 
experience in the construction industry and IBS project. All these data are nominal scales. Other sections (2 and 3 ) are as regards to the understanding of IBS and the perception and readiness of IBS usage in construction projects.

\subsection{Section 1: Respondents' background}

Table 1 depicts the majority of respondents are constructor which comprise of Bumiputera contractors and supplier with $82.19 \%$ of total respondents. In terms of their background in construction industry, majority of respondents are considered at senior level since $46.58 \%$ of respondents are having more than 10 years' experience. On the other hand, their experience in IBS projects are not abreast with their construction industry experience where majority of the respondents having less than 5 years' experience in IBS project.

Table 1. Respondent's designation and experience.

\begin{tabular}{|l|c|c|c|}
\hline \multicolumn{1}{|c|}{ Category } & Classification & Frequency & Percentage (\%) \\
\hline Designation & Client & 13 & 17.81 \\
\cline { 2 - 4 } & Constructor & 60 & 82.19 \\
\hline \multirow{2}{*}{$\begin{array}{l}\text { Respondents' experience in } \\
\text { the construction projects }\end{array}$} & $<5$ years & 14 & 19.18 \\
\cline { 2 - 4 } & $5-10$ years & 25 & 34.25 \\
\cline { 2 - 4 } & $>10$ years & 34 & 46.58 \\
\hline \multirow{2}{*}{$\begin{array}{l}\text { Respondents' experience in } \\
\text { the IBS projects }\end{array}$} & $<1$ years & 15 & 20.00 \\
\cline { 2 - 4 } & $<5$ years & 22 & 69.33 \\
\cline { 2 - 4 } & $5-10$ years & 5 & 6.67 \\
\cline { 2 - 4 } & $>10$ years & 3 & 4.00 \\
\hline
\end{tabular}

\subsection{Section 2: Understanding IBS}

Realibility Statistics on Section 2 is shown in the Table 2. The alpha value shows that the reliability of scale is considered acceptable which closed to 0.6 (alpha is 0.557 ) [10]. One sample t-test shows that all factors are statistically significant $(\mathrm{p}<0.05,2$-tailed).

Table 2. Reliability Statistics on Section 2.

\begin{tabular}{|c|c|c|}
\hline Cronbach's Alpha & $\begin{array}{c}\text { Cronbach's Alpha Based on Standardized } \\
\text { Items }\end{array}$ & N of Items \\
\hline 0.557 & 0.563 & 7 \\
\hline
\end{tabular}

Table 3 shows the mean score for respondent's understanding on IBS. This is crucial to gather this information in order to identify level of understanding and knowledge of IBS among Bumiputera construction players. There are 7 relevant variables have been asked to the respondents in getting the feedback. Generally, all respondents rated mean above 3.00, which ranging from 3.3919 to 4.1892. Out of all variables, it is found that most of respondents agree on the argument that IBS manage to improve and modernise the conventional or traditional construction method (mean $=4.1892$ ). This is then followed by the awareness among the respondents on the government roles on the enforcement to the construction players in adopting IBS in construction projects. Nevertheless, it is indispensable to note the lowest rank variable by the respondents which is towards negative variable. Respondents found that IBS in Malaysia is not well accepted by construction players in the supply chain since the IBS operation payment is difficult. This is due to the condition where the payment method being used for IBS project is identical to payment method for conventional or traditional project. This has 
discouraged construction players in engaging to IBS. Therefore, the payment method and mechanism is required in bettering the situation since IBS adopters require reliable and safer payment and procurement [5].

Table 3. Respondent's understanding on IBS.

\begin{tabular}{|c|c|c|c|c|}
\hline \multicolumn{5}{|c|}{ Respondent's Understanding on IBS } \\
\hline $\begin{array}{l}\text { Variables } \\
\end{array}$ & $\mathbf{N}$ & Mean & Std. Deviation & Ranking \\
\hline Familiarity with the IBS construction methods & 75 & 3.4400 & 1.01662 & 6 \\
\hline $\begin{array}{l}\text { Government enforcement in adapting IBS in } \\
\text { construction projects }\end{array}$ & 75 & 3.8533 & 0.84938 & 2 \\
\hline $\begin{array}{ll}\text { IBS usage } & \text { gives the opportunity to all } \\
\text { construction } & \text { players to participate in IBS } \\
\text { projects } & \end{array}$ & 74 & 3.6216 & 0.85533 & 4 \\
\hline $\begin{array}{l}\text { IBS can improve and modernize the } \\
\text { conventional construction method }\end{array}$ & 74 & 4.1892 & 0.77062 & 1 \\
\hline $\begin{array}{l}\text { The price of IBS components is controlled by } \\
\text { manufacturers/suppliers }\end{array}$ & 75 & 3.7467 & 1.05386 & 3 \\
\hline $\begin{array}{l}\text { IBS in Malaysia is not well accepted by } \\
\text { construction players in the supply chain } \\
\text { because the IBS operation and payments are } \\
\text { difficult }\end{array}$ & 74 & 3.3919 & 0.88855 & 7 \\
\hline $\begin{array}{l}\text { Lack of support and slow adoption of IBS from } \\
\text { the private sector }\end{array}$ & 73 & 3.5205 & 0.91454 & 5 \\
\hline
\end{tabular}

\subsection{Section 3: Perception and readiness of IBS usage in construction projects}

Realibility Statistics on Section 3 is shown in the Table 4. The alpha value indicates that the reliability of scale is acceptable (alpha is 0.60 ). The original value is 0.477 if all questions remained in the analysis. Therefore, one factor was deleted to improve the reliability. One sample t-test shows that all factors are statistically significant ( $\mathrm{p}<0.05,2$-tailed).

Table 4. Reliability statistics on section 3.

\begin{tabular}{|c|c|c|}
\hline Cronbach's Alpha & $\begin{array}{c}\text { Cronbach's Alpha Based on Standardized } \\
\text { Items }\end{array}$ & N of Items \\
\hline 0.477 & 0.812 & 12 \\
\hline
\end{tabular}

Table 5 shows the perception and readiness by the respondents towards the usage of IBS in construction project. It is found that the majority of respondents are in favour that it is not difficult in learning and being skilful in adapting IBS in the construction project (mean score $=4.5068$ ). This indicates that Bumiputera construction players are keen and interested in the application of IBS or their projects. This is supported with the awareness on the need to train conventional small and medium scale contractors on the application of IBS which promotes and adding value for them and widening the opportunity in construction industry. In addition, installing IBS components require precision and stability for instance, the installation for suspended beam and slab should be perfectly levelled and positioned as per stipulated in the design [11]. Besides, specialized and additional engineering knowledge are required in designing, manufacturing and constructing a functional IBS components. It is necessary for all parties involved from designers to erectors to have sufficient and decent knowledge on IBS practice [12]. In order to keep abreast with the current needs and scenario of Malaysia construction industry, Bumiputera construction players are required to equip themselves with the IBS knowledge besides encouraging more participation of the IBS projects by the government. However, respondents' perception towards the issue of storage and transportation of the IBS components to be manageable are rated as the least preferable by the respondents (mean score $=$ 3.5205). This is due to the current situation of IBS application which requires high efficiency and 
accuracy in coordination in order to avoid problems of storage and transporting the IBS components to the site as well as the installation. Failure in coordination and lack of competency in handling IBS components might result in serious problem such as delay in project delivery, difficulty in managing payments to the IBS suppliers and contractors and wastage of materials in producing IBS components.

Table 5. Perception and readiness of IBS usage in construction projects.

\begin{tabular}{|l|c|c|c|c|}
\hline \multicolumn{5}{|c|}{ Perception and readiness of IBS usage in construction projects } \\
\hline \multicolumn{1}{|c|}{ Variables } & N & Mean & Std. Deviation & Ranking \\
\hline $\begin{array}{l}\text { Learning the concept of IBS is easy for the } \\
\text { company }\end{array}$ & 73 & 3.8767 & 0.84894 & 8 \\
\hline It is easy for the company to get info on IBS & 73 & 3.6575 & 0.88536 & 10 \\
\hline $\begin{array}{l}\text { The transportation \& storage of IBS component } \\
\text { to be manageable }\end{array}$ & 73 & 3.5205 & 1.01529 & 11 \\
\hline $\begin{array}{l}\text { The installation of IBS components will } \\
\text { required fewer workforce }\end{array}$ & 73 & 3.8219 & 0.83902 & 9 \\
\hline $\begin{array}{l}\text { It is easy for the company to become skilful at } \\
\text { using IBS }\end{array}$ & 73 & 4.5068 & 6.06704 & 1 \\
\hline $\begin{array}{l}\text { Using IBS would improve overall project } \\
\text { performance and quality }\end{array}$ & 72 & 4.0139 & 0.83063 & 3 \\
\hline $\begin{array}{l}\text { Using IBS would enhance project delivery } \\
\text { efficiency }\end{array}$ & 73 & 3.9315 & 0.87128 & 6 \\
\hline $\begin{array}{l}\text { Using IBS would make it easier to complete a } \\
\text { project }\end{array}$ & 73 & 3.9863 & 0.84151 & 4 \\
\hline IBS is useful in delivering construction projects & 73 & 3.8904 & 0.87499 & 7 \\
\hline $\begin{array}{l}\text { Conventional SMEs (G3-G5) contractors should } \\
\text { be trained to become IBS contractors }\end{array}$ & 73 & 4.1370 & 0.73248 & 2 \\
\hline $\begin{array}{l}\text { Local SMEs (G3-G5) contractors are still } \\
\text { lacking in respondent's area }\end{array}$ & 73 & 3.9726 & 0.89710 & 5 \\
\hline
\end{tabular}

\section{Summary}

The research manages to reveals that Bumiputera construction players are aware with implementation of IBS and already equipped with the knowledge and skill of IBS. Level of understanding is at satisfactorily level and depicts the positive indication on the adoption of IBS among them. Their optimistic view on the perception towards IBS indicates the keenness of IBS usage in future projects. Nonetheless, issues on method of payment for IBS project and coordination on transportation and storage of IBS components need to be further discussed in improving IBS project delivery. Further research are required in order to identify the critical success factors and determinants for the implementation of IBS among Bumiputera in Malaysia construction industy.

\section{Acknowledgements}

These researchers would like to express gratitude for the financial support from Kementerian Pendidikan Malaysia (KPM) under purview of Research Acculturation Grant Scheme (RAGS) 600RMI/RAGS 5/3 (237/2014) and Research Management Institute (RMI) Universiti Teknologi MARA (UiTM).

\section{References}

[1] K.A.M. Kamar, Z.A. Hamid and N. Dzulkalnine, Industrialised building system (IBS) construction, measuring the perception of contractors in Malaysia, IEEE Business, Engineering and Industrial Applications Colloquium, (2012). 
[2] Construction Industry Development Board, IBS Roadmap, Kuala Lumpur, (2003).

[3] K.A.M. Kamar, M. Alshawi and Z.H. Hamid, Barriers to industrialised building system (IBS), The case of Malaysia, Proc. of International Postgraduate Research Conference, (2009).

[4] W.A. Thanoon, L.W. Peng, M.R. Abdul Kadir, M.S. Jaafar and M.S. Salit, The essential characteristics of industrialised building system, Proc. of International Conference on Industrialised Building Systems, Kuala Lumpur, 283-292, (2003).

[5] M.F. Musa, M.F. Mohammad, M.R. Yusof and R. Mahbub, The way forward for industrialised building system (IBS) in Malaysia, Proc. of the International Civil and Infrastructure Engineering Conference, 163-175, (2015).

[6] A.S. Abd Shukor, M.F. Mohammad, R. Mahbub and F. Ismail, Supply chain integration in industrialised building system in the Malaysian construction industry, The Built and Human Environment Review, 4(1), (2011). <retrieved from http://www.tbher.org/index.php /tbher/article/view/48>

[7] M. Jaafar, T. Ramayah and A.H.M. Salleh, Adaptation strategies of contracting firms: An analysis by firm size, Proc. International Conference in the Built Environment in the 21st Century, Kuala Lumpur, 387-394, (2006).

[8] M.Q. Oleiwi, Industrialized Building System: A Malaysian Approach, Filspay Academy, (2015).

[9] Construction Industry Development Board, Transformation of construction industry through industrialized building system (IBS) roadmap, (2011).

[10] S. Moss, H. Prosser, H. Costello, N. Simpson, P. Patel, S. Rowe, S. Turner and C. Hatton, Reliability and validity of the PAS-ADD checklist for detecting psychiatric disorders in adults with intellectual disability, Journal of Intellectual Disability Research, 42,173-83, (1998).

[11]A.M. Abdullah and S.A. Malik, Key indicators of SWOT analysis between bumiputera and nonbumiputera industrialized building system (IBS) contractors in Selangor, Proc. of International Conference on Statistics in Science, Business and Engineering, (2012).

[12]A.B. Rahman and W. Omar, Issues and challenge in the implementation of IBS in Malaysia, Proc. of the 6th Asia Pacific Structural Engineering and Construction Conference, Kuala Lumpur, (2006). 